\title{
SERTIFERA, A NEW GENERIC RECORD FOR THE PERUVIAN ORCHID FLORA
}

\author{
Delsy Trujillo ${ }^{1-3,6} \&$ Margoth Acuña-Tarazona ${ }^{4,5}$ \\ ${ }^{1}$ Facultad de Ingeniería Agraria, Universidad Católica Sedes Sapientiae, Jirón Manuel Gonzales Prada \\ Mz. Unica Sub-lote 4-B, Urb. Villa Los Ángeles, Los Olivos, Lima, Perú \\ ${ }^{2}$ Herbario San Marcos (USM), Museo de Historia Natural de la Universidad Nacional Mayor de San \\ Marcos, Lima, Perú \\ ${ }^{3}$ Herbario MOL, Facultad de Ciencias Forestales, Universidad Nacional Agraria La Molina, Perú \\ ${ }^{4}$ Red de Ecología Funcional, Instituto de Ecología A. C., Xalapa, Veracruz, México \\ ${ }^{5}$ Laboratorio de Gymnospermas y Monocotiledóneas, Museo de Historia Natural, Jesús María, Perú \\ ${ }^{6}$ Author for correspondence: dtrujillo@ucss.edu.pe
}

\begin{abstract}
An orchid species, previously known from Northern Andes, is reported for first time in Peru: Sertifera purpurea. A description, illustration, photographs, and comments about the species are provided.

Resumen. Una especie de orquídea, previamente conocida de los Andes del Norte, se reporta por primera vez para el Perú: Sertifera purpurea. Se presenta una descripción, ilustración, fotografías y comentarios sobre la especie.
\end{abstract}

Key words / Palabras clave: Bosque de Protección Alto Mayo, Peru, Sobralieae

Introduction. There are currently four recognized genera in the Neotropical tribe Sobralieae: Elleanthus C. Presl, Epilyna Schltr., Sertifera Lindl. \& Rchb.f, and Sobralia Ruiz \& Pav. (including Brasolia (Rchb.f.) Baranow, Dudek \& Szlach.) (Neubig et al. 2011, Chase et al. 2015, Baranow, Dudek \& Szlachetko 2017).

Orchids of the genus Sertifera have relatively small flowers of bright colors, which resemble the flowers of Elleanthus. Vegetatively, Sertifera, like Elleanthus and Sobralia, are caespitose plants with slender, elongate cane-like stems and plicate leaves. However, Sertifera is easily distinguished from the other genera of the tribe by having leaf sheaths with tubercles, axillary and secund or subcapitate inflorescences, and flattened peduncle.

Lindley and Reichenbach (Reichenbach 1877) described Sertifera with two species: S. purpurea Lindl. \& Rchb.f. from Ecuador (with "lateral corymbose" inflorescence) and S. virgata Rchb.f. from Peru (with terminal racemes inflorescence). However, the latter was transferred by Schweinfurth (1938) to Elleanthus. The second species of Sertifera, from Ecuador, was described by Kraenzlin (1899) but hiding under the name of Diothonea lehmanniana Kraenzl. (transferred to Sertifera by Garay in 1978). Schlechter (1920, 1924) then described three species from Colombia: Sertifera colombiana Schltr., S. major Schltr. and S. parviflora Schltr. Subsequently, Williams (1939) and Schweinfurth (1946) described two more species from the same country: S. grandifolia L.O.Williams and $S$. aurantiaca C.Schweinf., respectively. Recently, another three species have been proposed for Colombia: S. gracilis Rchb.f. ex Szlach. \& Baranow, S. risaraldana Szlach. \& Baranow and S. albiflora Szlach., Kolan. \&. MedinaTr., (Szlachetko \& Baranow 2014, Szlachetko, Kolanowska \& Medina Trejo 2014). Thereby, at the moment ten species are referable to Sertifera.

Sertifera has been referred as a genus restricted to the northern Andes, species have been reported from Ecuador, Colombia, and Venezuela between 1,000 and 3,600 m of elevation (Schlechter 1924, Szlachetko \& Baranow 2014).

Recent field work in the North of Peru revealed the presence of populations of S. purpurea; which represent the first record for this country. Previously, 

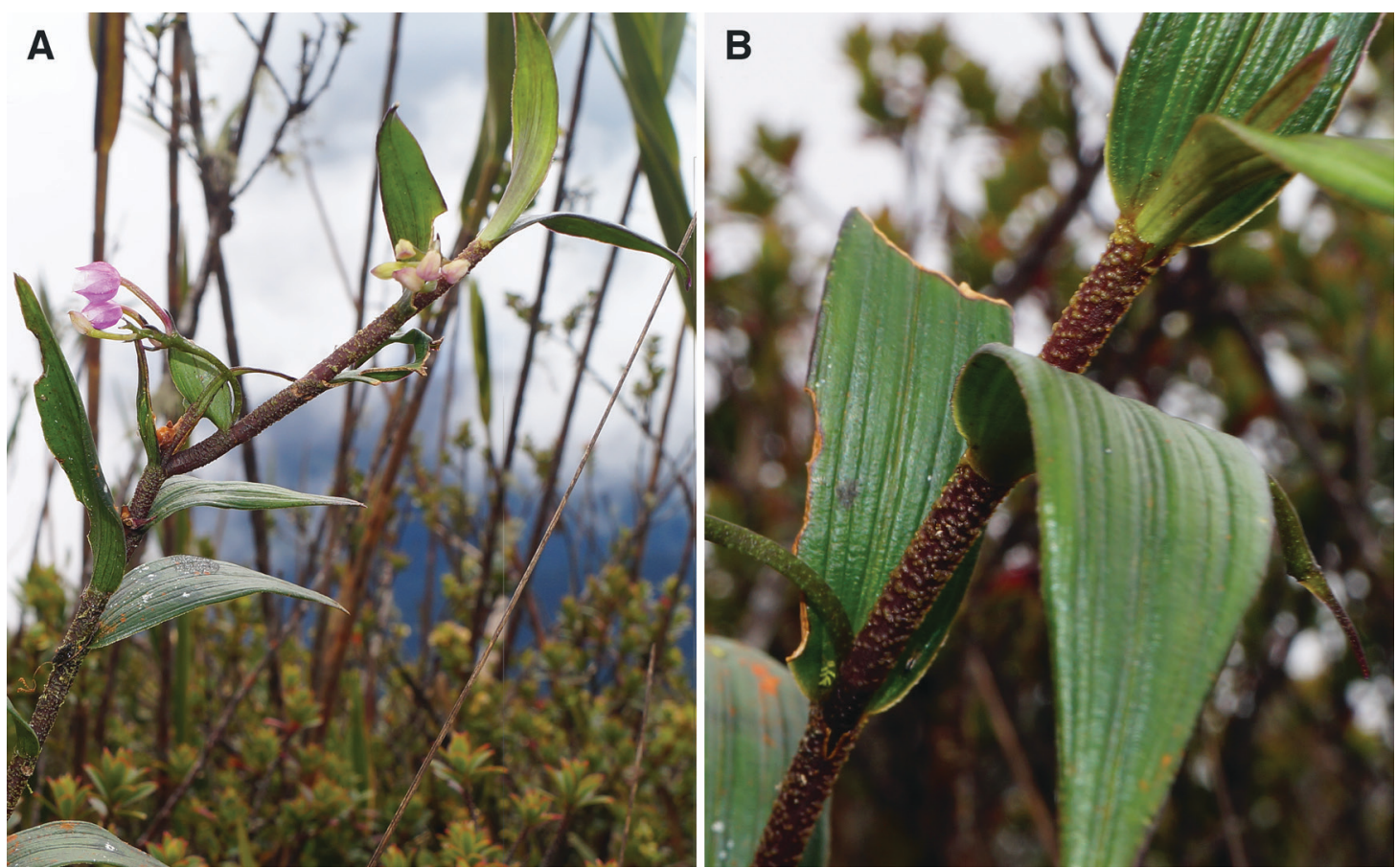

FiguRE 1. Sertifera purpurea. A. Plant in its natural habitat showing a branched stem. B. Verrucose leaf sheaths. Photographs by J. Edquén.

during a Rapid Assessment in The Cordillera del Cóndor, next to the Ecuadorian border, two specimens (one sterile) were collected and identified as Sertifera sp. (Schulenberg \& Awbrey 1997). Those specimens are housed at MOL and were examined for this present study. Here, we formally record the genus Sertifera for Peru and provide a description of Sertifera purpurea based on the Peruvian specimens.

\section{TAXONOMIC TREATMENT}

Sertifera purpurea Lindl. \& Rchb.f., Linnaea 41: 64. 1877.

TYPES: Ecuador, [Andes Quitensis], TungurahuaSpruce 5394 (syntype: W-76627, photo seen, designated as lectotype by Garay, 1978). Ecuador, [Quito], Jameson s.n. (syntype W-76625, photo seen). Ecuador, [Valley of Lloa, 1857], Jameson s.n. (syntype: K-501912, photo seen, (mixed), photo at AMES). Ecuador, [from the forest on the western slope of the Andes, 1854] Jameson s.n. (syntype: K-501912, photo seen, (mixed), photo at AMES).

Synonym: Sertifera lehmanniana (Kraenzl.) Garay,
Fl. Ecuador 9: 135. 1978. Diothonea lehmanniana Kraenzl., Bot. Jahrb. Syst. 26: 489. 1899. TYPE: Ecuador. Pichincha: Western declivity of Cerro Corazón, near Canchacoto on Río Pilatón, [2000 m, Jan 1881], Lehmann 126 (G-422011, photo seen, lectotype, designated by Garay, 1978; isolectotype G[x2], photos seen, HUH-82476 [flower at AMES ex G], photo seen).

Plant terrestrial, up to $1 \mathrm{~m}$ tall. Stem cane-like, erect to slightly arcuate, enclosed by reddish brown verrucose tubular leaf sheaths, unbranched (rarely branched), leafy above (Fig. 1A, B). Leaves somewhat coriaceous, blades ovate-lanceolate to ellipticlanceolate, acuminate, plicate, margins minutely erose, sessile on tubular sheaths, 3.1-7.7 $\times 0.7-1.8$ $\mathrm{cm}$. Inflorescence axillary, arcuate, subcapitate, shorter than the subtending leaf; peduncle flattened, 1.0-2.5 cm long; rachis $0.7-1.0 \mathrm{~cm}$ long, 6 to 8 flowers. Floral bracts linear-lanceolate, acute to acuminate, green turning blackish purple, $2.0-4.5 \mathrm{~mm}$ long (decreasing in size towards the apex). Flowers globose, sepals and petals pink to purplish, lip and tip of petals white (Fig. 2A); ovary and pedicel green to red-violet. Dorsal 

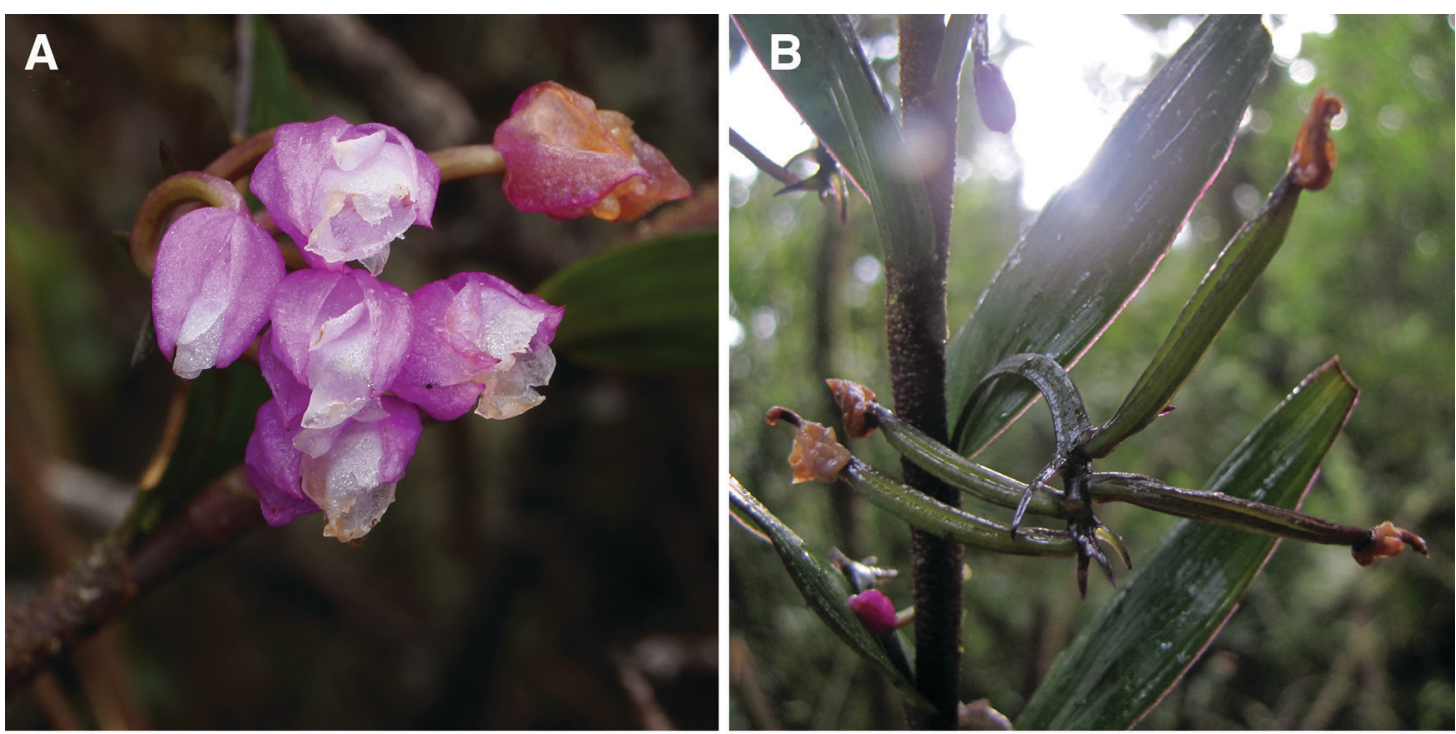

C

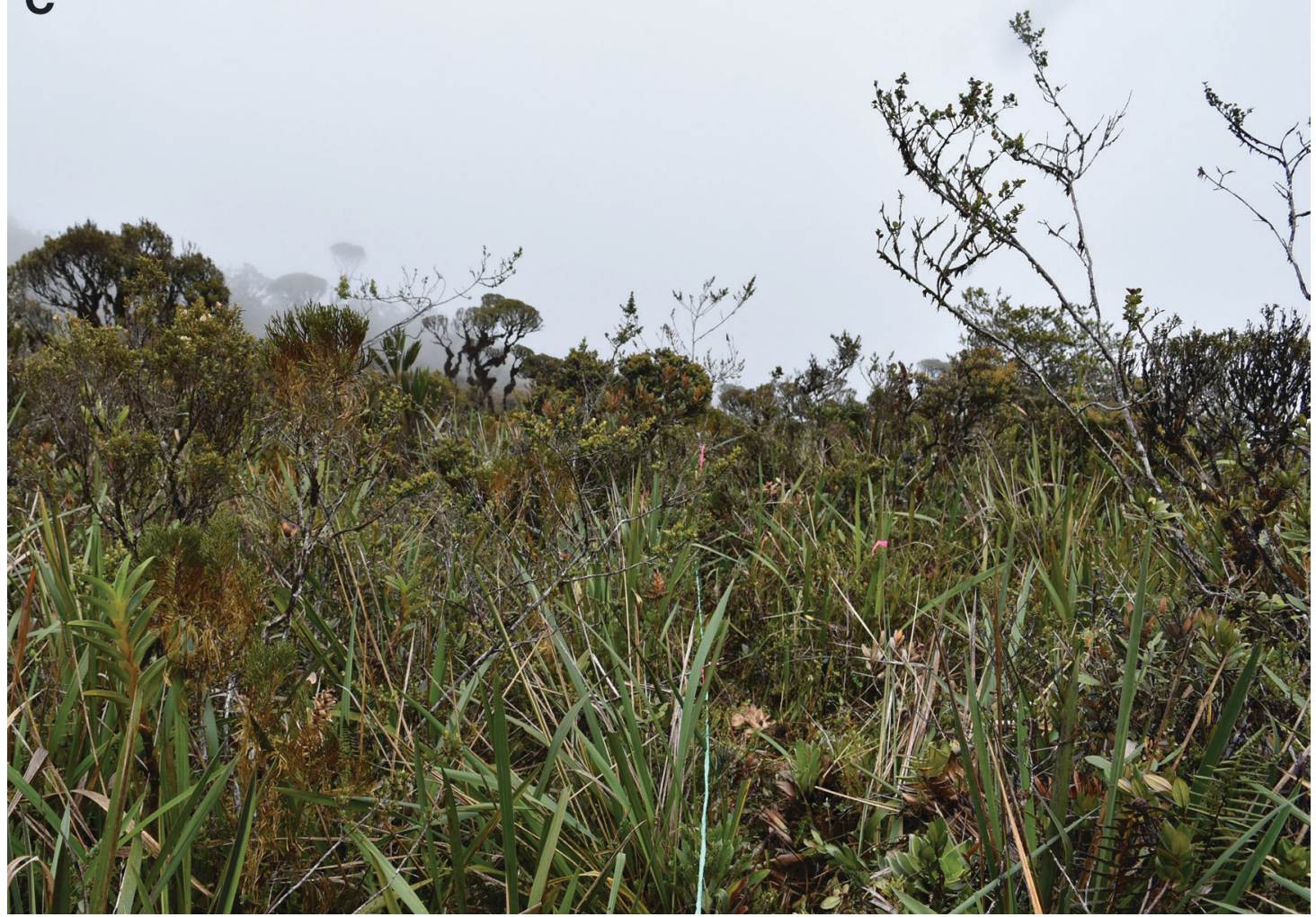

FiguRE 2. Sertifera purpurea A. Inflorescence B. Fruits, C. Habitat. Photographs A by J. Edquén; B, C by M. Acuña-Tarazona.

sepal elliptic, acute to obtuse, minutely mucronate at apex, 3-nerved, 5.5-6.5 × 3-4 mm. Lateral sepals slightly connate at base, oblique, elliptic, acute, mucronate, dorsally carinate, 3-nerved, 6-7 × 3-4 mm.
Petals ovate-elliptic to subrhombic, obtuse, somewhat undulate towards the apex, 1-nerved (sometimes with 1 or 2 short lateral nerves), $5-7 \times 3.0-3.5 \mathrm{~mm}$. Lip enfolding the column, basally saccate, conduplicate, 

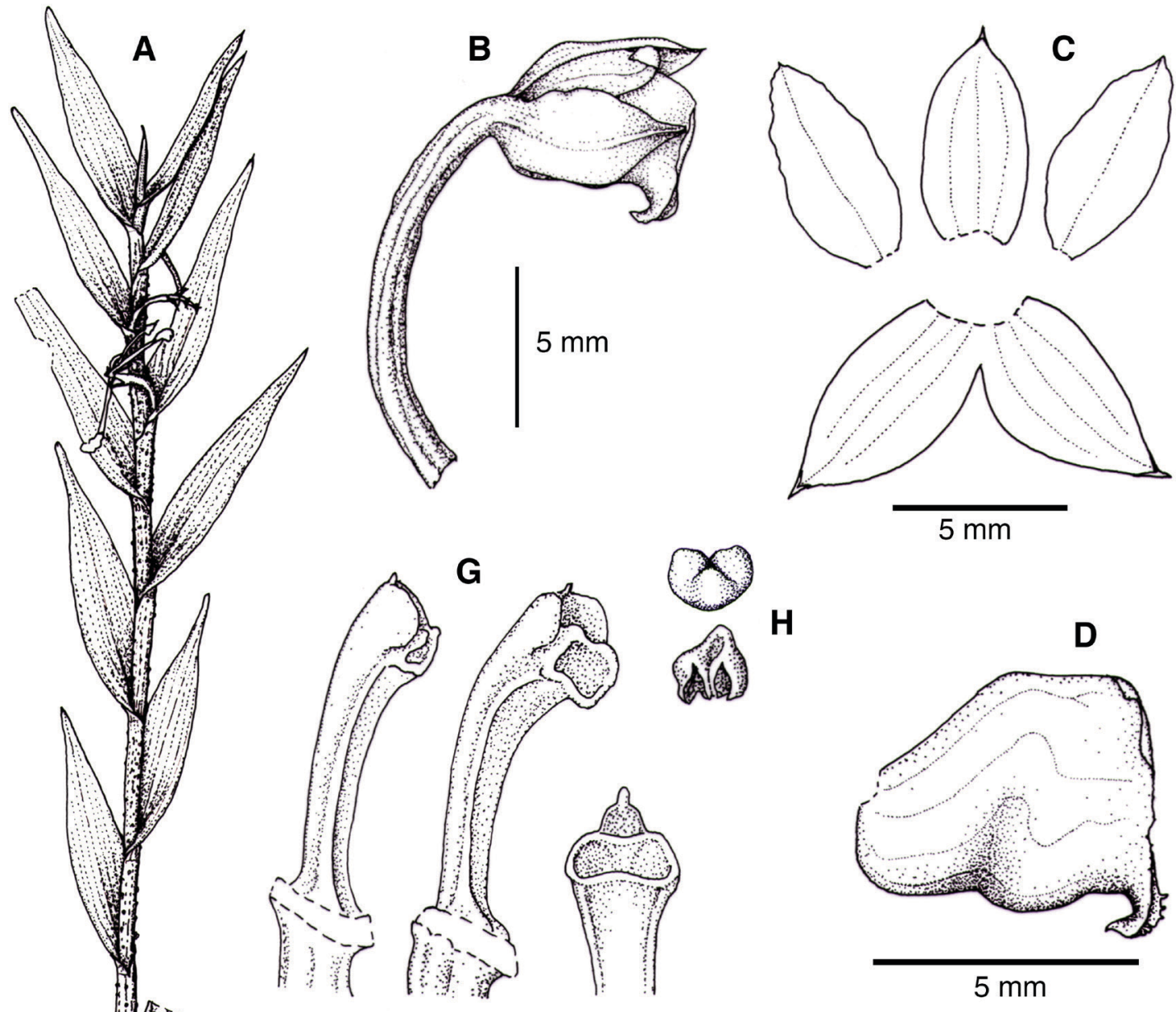

$5 \mathrm{~mm}$
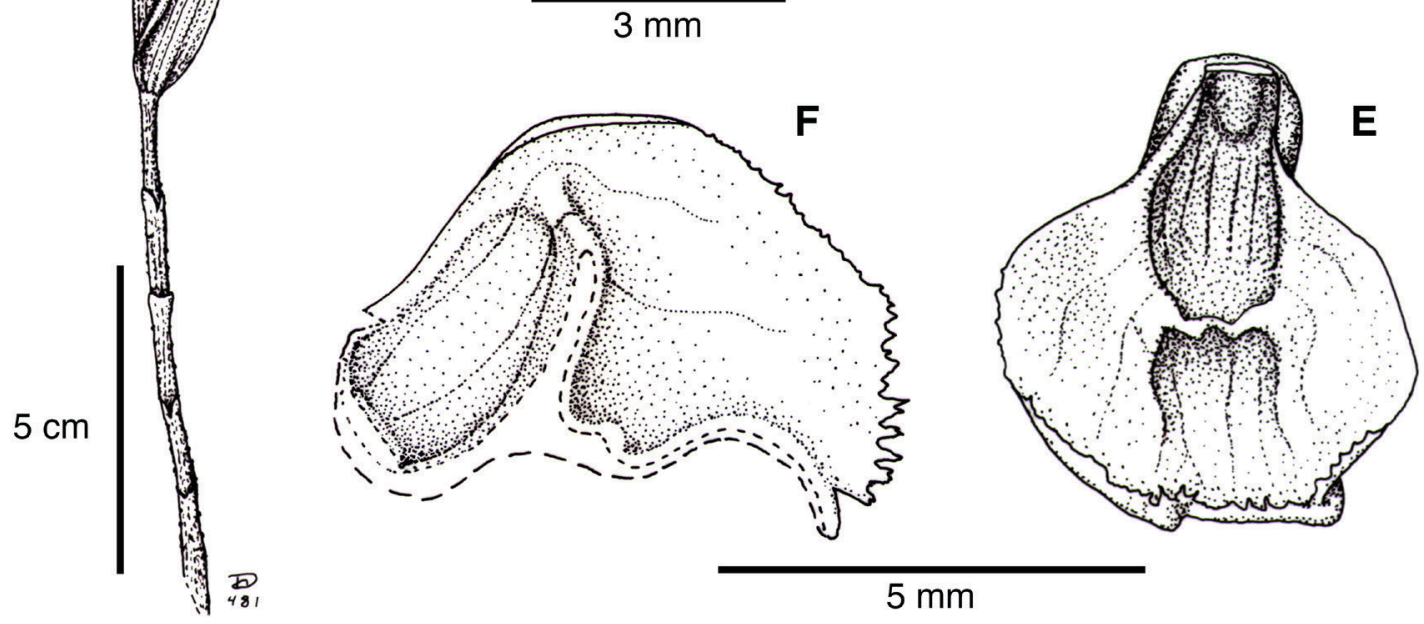

Figure 3. Sertifera purpurea. A. Habit. B. Flower. C. Dissected perianth. D. Lip. lateral view. E. Lip, ventral view, F. Lip, longitudinal section. G. Column (from two different flowers). H. Anther cap. Drawing by D. Trujillo based on $M$. Acuña 1803 (USM). 
flattened laterally, seen from the side subquadrateobovate, when expanded transversely elliptic, base of the lip thickened, with a small callus, disc provided with a transverse, plate-like ridge which holds the two sides together, the upper margins involute and irregularly erose to shortly lacerate, $5.5-7.0 \mathrm{~mm}$ long. Column slender, slightly curved upward, auriculate at apex, 3.5-5.0 mm long. Anther reniform, $1 \mathrm{~mm}$ long. Stigma bilobed. Ovary cylindric, curved, glabrous, 7-14 mm long. Fruit narrowly ellipsoid, 13-17 × 2-5 mm (Figs. 2B, 3).

Specimen examined: Peru. [Amazonas, Prov. Condorcanqui], Cordillera del Cóndor, [July -August 1994] M. Cavero 1636 (MOL). San Martín, Prov. Rioja, Distrito Pardo Miguel Naranjos, Bosque de Protección Alto Mayo, 2500 m, 13 April 2017, M. Acuña et al. 1803 (USM). Same locality, 3053 m, 23 May 2017, M. Acuña et al. 1969 (USM).

Other specimens: Peru [Amazonas, Prov. Condorcanqui], Cordillera del Cóndor, [July -August 1994], M. Cavero 1627 (MOL [sterile]).

Distribution: Venezuela, Colombia, Ecuador, and Peru. In Peru, it is known in the Departments of Amazonas and San Martín, between 2,150 and 3,053 m elevation (Fig. 4).

Habitat and ecology: Plants of this species were found growing in shrub vegetation with small trees up to $5 \mathrm{~m}$ tall, dominated by Podocarpus oleifolius D.Don ex Lamb., Clusia sp., Weinmannia sp., Miconia sp., and Myrcia sp., and open areas with herbs and small shrubs (Fig. 2C). Individuals with flowers and fruits were recorded in April, May and October.

Sertifera purpurea and S. lehmanniana were described based on plants from the north-central Andes of the Ecuador. The type specimens of $S$. purpurea were collected in the Province of Tungurahua (Spruce 5394) and the Province of Pichincha: Quito (Jameson s.n.) and in the Valley of Lloa (Jameson s.n.). The type specimen of $S$. lehmanniana was collected in the Province of Pichincha: west of Cerro Corazon (south of Quito), near Canchacoto (Lehman 126). Both species display similar morphological features. Based on examination of the herbarium specimens (digital images) and a dissected flower of the lectotype

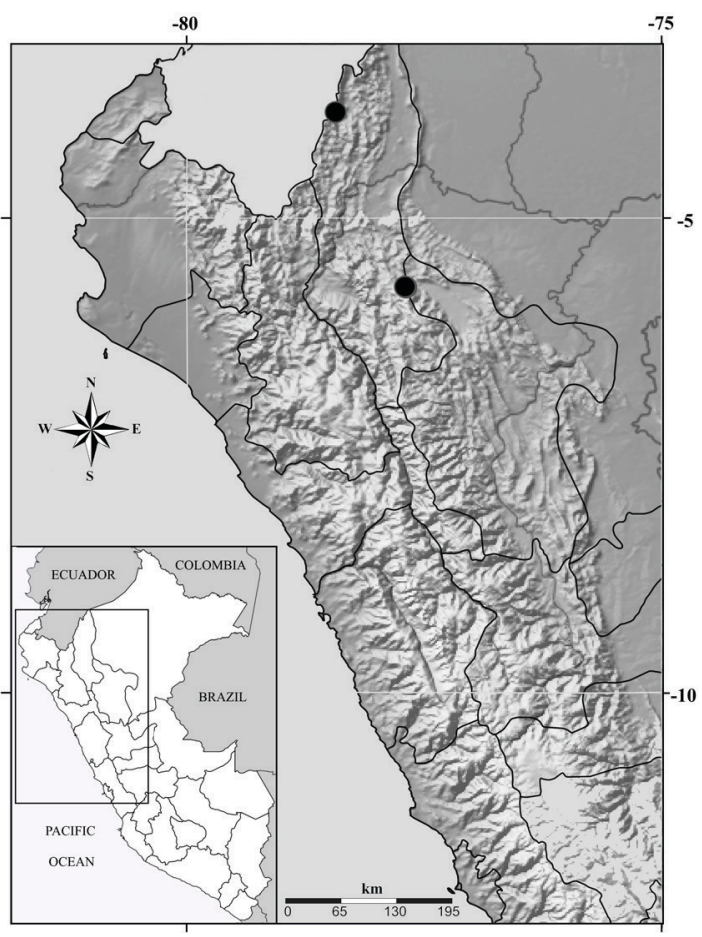

FIgURE 4. Distribution map of Sertifera purpurea (black circles) in Peru.

of $S$. lehmanniana (microscope slide prepared by Garay, HUH-82476), the feature that distinguishes S. lehmanniana from $S$. purpurea is that the first displays ovate-oblong to ovate-ligulate petals ( $v s$. ovate-elliptic to subrhombic). Dunsterville and Garay (1966) considered that they both represent the same species and placed $S$. lehmanniana as synonym of $S$. purpurea; we agree with that assessment.

Sertifera colombiana is also similar to $S$. purpurea (Schlechter 1920, Mansfeld 1929, plate 13, nr. 46); however, additional research is necessary to state whether they are the same species.

ACKNOWLEDGEMENTS. We thank the staff and curators of AMES, K, G, and $\mathrm{W}$ for their help looking for the type material in their institutions. We also thank Stig Dalström and Günter Gerlach for their help with the bibliography; José Edquén for providing photographs of Sertifera purpurea. M. Acuña-Tarazona thanks to the Peruvian authorities for granting a permission for collecting plant specimens (research permit $\mathrm{N}^{\circ}$ 007-2016-SERNANP-BPAM-JEF). M. Acuña-Tarazona also thanks Roner Espinar, Juan Cusi, Elluz Huamán, José Ramírez, José Edquén, and Elmer Mondragon for their invaluable help during the 
fieldwork. The Rufford Foundation (grant no. 18872-1) and the American Orchid Society supports the work to M. Acuña-Tarazona., who also acknowledges CONACYT (no.
280642) for supporting her Ph.D. studies at the Instituto de Ecología, A. C. We also thank anonymous reviewers for commenting on and improving the manuscript.

\section{LITERATURE CITED}

Baranow, P., Dudek, M. \& Szlachetko, D. L. (2017). Brasolia, a new genus highlighted from Sobralia (Orchidaceae). Plant Systematics and Evolution, 303, 853-871. doi: 10.1007/s00606-017-1413-z

Chase, M. W., Cameron, K. M., Freudenstein, J. V., Pridgeon, A. M., Salazar, G., Van den Berg, C. \& Schuiteman, A. (2015). An updated classification of Orchidaceae. Botanical Journal of the Linnean Society, 177, 151-174.

Dunsterville, G. C. K. \& Garay, L. A. (1966). Venezuelan Orchids Illustrated V. London: Andre Deutsch Limited.

Garay, L. A. (1978). Orchidaceae (Cypripedioideae, Orchidoideae, Neottioideae). Pp.1-305 In: G. Harling \& B. Sparre (Eds.), Flora of Ecuador 9. Göteborg and Stockholm: University of Goteborg and Swedish Museum of Natural History.

Kraenzlin, F. (1899). Orchidaceae Lehmannianae in Guatemala, Costa-Rica, Columbia et Ecuador collectae, quas determinavit et descripsit. Botanische Jahrbücher für Systematik, Pflanzengeschichte und Pflanzengeographie, 26, 437-502.

Mansfeld, R. (Ed.). (1929). Figuren-Atlas zu den Orchideenfloren der südamerikanischen Kordillerenstaaten. Repertorium Specierum Novarum Regni Vegetabilis, Beihefte, 57.

Neubig, K. M., Whitten, W. M., Blanco, M. A., Endara, L., Williams, N. H. \& Koehler, S. (2011). Preliminary molecular phylogenetics of Sobralia and relatives (Orchidaceae: Sobralieae). Lankesteriana, 11(3), 307318. doi: 10.15517/LANK.V11I3.18286

Reichenbach, H. G. (1877). Orchidiographische Beitraege. Linnaea, 41, 17-98.

Schlechter, R. (1920). Die Orchideenfloren der südamerikanischen Kordillerenstaaten II. Colombia. Repertorium Specierum Novarum Regni Vegetabilis, Beihefte, 7, 1-301.

Schlechter, R. (1924). Beiträge zur Orchideenkunde von Colombia I. Orchidaceae Hoppianae. Repertorium Specierum Novarum Regni Vegetabilis Beihefte, 27, 5-123

Schulenberg, T. \& Awbrey, K. (Eds.). (1997). The Cordillera del Condor region of Ecuador and Peru: A biological assessment. RAP Working Papers Number 7. Washington, D.C.: Conservation International.

Schweinfurth, C. (1938). Nomenclatorial notes VII. Botanical Museum Leaflets, 6(5), 112.

Schweinfurth, C. (1946). Orchidaceae Andinae-II. Revista de la Academia Colombiana de Ciencias Exactas, Físicas y Naturales, 6, 573-577.

Szlachetko, D. L. \& Baranow, P. (2014). Notes on the Genus Sertifera (Orchidaceae, Epidendroideae). Systematic Botany, 39(1), 41-54. doi: 10.1600/036364414X678143

Szlachetko, D. L., Kolanowska, M. \& Medina Trejo, R. (2014). First white-flowered species of Sertifera (Orchidaceae) discovered in Colombia. Biodiversity: Research and Conservation, 35, 19-24. doi: 10.2478/ biorc-2014-0019

Williams, L. O. (1939). Orchidaceae Austro-Americanae I. Lilloa, 5, 5-11. 